\title{
Cytokines, chemokines and other effector molecules involved in meningococcal disease
}

\author{
S. J. HACKETT*†, A. P. J. THOMSON ${ }^{\dagger}$ and C. A. HART* \\ $\dagger$ Institute of Child Health, Royal Liverpool NHS Trust-Alder Hey, Eaton Road, Liverpool L12 2AP and \\ * Department of Medical Microbiology, University of Liverpool, Daulby Street, Liverpool L69 $3 G A$
}

\begin{abstract}
This review examines the role of cytokines and chemokines in the pathogenesis of meningococcal disease (MCD) and draws comparisons with studies of other forms of sepsis in adults and in animal models. There are many similarities but also discrepancies between these data. MCD is a well-defined clinical syndrome with identifiable onset and time of presentation. It is a reliable model in which to study cytokine and chemokine responses in bacterial sepsis. Such studies may lead to new adjunctive treatments, which can be tested to ameliorate severe MCD.
\end{abstract}

\section{Background}

Meningococcal disease (MCD) remains the commonest infective cause of death in children in western societies. Despite the use of potent antibiotics and high-level intensive care, the mortality in children with severe meningococcaemia remains at $3-15 \%$ [1]. There is a wide spectrum of the clinical presentation of MCD. Transient bacteraemia has been recognised, but the commonest presentations are meningococcal septicaemia and meningitis [2]. Asymptomatic nasopharyngeal carriage of potentially pathogenic meningococci occurs in $2-25 \%$ of healthy people, of whom only a small minority develop invasive disease [3]. It is thought that the clinical features and sequelae seen in patients with severe MCD (and other forms of sepsis) are directly related to the load of Neisseria meningitidis in blood (see footnote to References) and the resulting host response. The outer membrane of $N$. meningitidis is rich in lipo-oligosaccharide (LOS) that is continually released by blebbing (Fig. 1). The release of LOS into serum in high concentrations is a potent stimulus of the patient's inflammatory pathways. This includes cytokines (pro- and anti-inflammatory), chemokines, soluble receptors, interferons and colony stimulating factors. The majority of this stimulation of the immune system occurs when either LOS or LOS bound to LOSbinding protein (LBP) binds to $\mathrm{CD}-14$ receptors coupled with Toll-like receptor 4 (TLR) mainly on macrophages, granulocytes and endothelium [4].

Received 12 Sept. 2000; revised version received 21 Dec. 2000; accepted 23 April 2001.

Corresponding author: $\operatorname{Dr}$ S. J. Hackett (e-mail: scott. hackett@liv.ac.uk).
Recent work has also demonstrated that immune stimulation by $N$. meningitidis can occur via an LOS/CD-14 independent mechanism that is probably mediated by TLR2 [4]. This effect, which is seen only at high bacterial concentrations $\left(\geqslant 10^{7}\right.$ bacteria $\left./ \mathrm{ml}\right)$ [5], may explain why some patients develop a more severe illness than others. This is supported by the recent finding that disease severity in $\mathrm{MCD}$, measured by the Glasgow Meningococcal Septicaemia Prognostic Score (GMSPS) and death, correlated significantly with bacterial load on admission (median load in severe disease $>10^{7}$ bacteria $/ \mathrm{ml}$; see footnote to References).

In MCD (and all forms of sepsis) there is a complex interaction between cytokines and a wide variety of immune and non-immune system cells. The central cellular components are the $\mathrm{CD}^{+} \mathrm{T}$ cells, polymorphonuclear cells, monocyte/macrophage lineage and the vascular endothelium, with the latter two probably being the most important. This paper will give an overview of the role of each of the cytokines studied so far in paediatric MCD and compare and contrast this to adult and experimental models of sepsis. Where it is not stated, the studies described are in-vitro experiments.

The cytokines that have been studied in MCD have been arranged into the categories in Table 1. The molecules in each of the groups often have only limited structural and evolutionary relationships, but they do share similar biological functions. All the groups in Table 1, with the exception of the receptors, should really be placed under the umbrella heading of cytokines. A cytokine can be defined as a soluble 


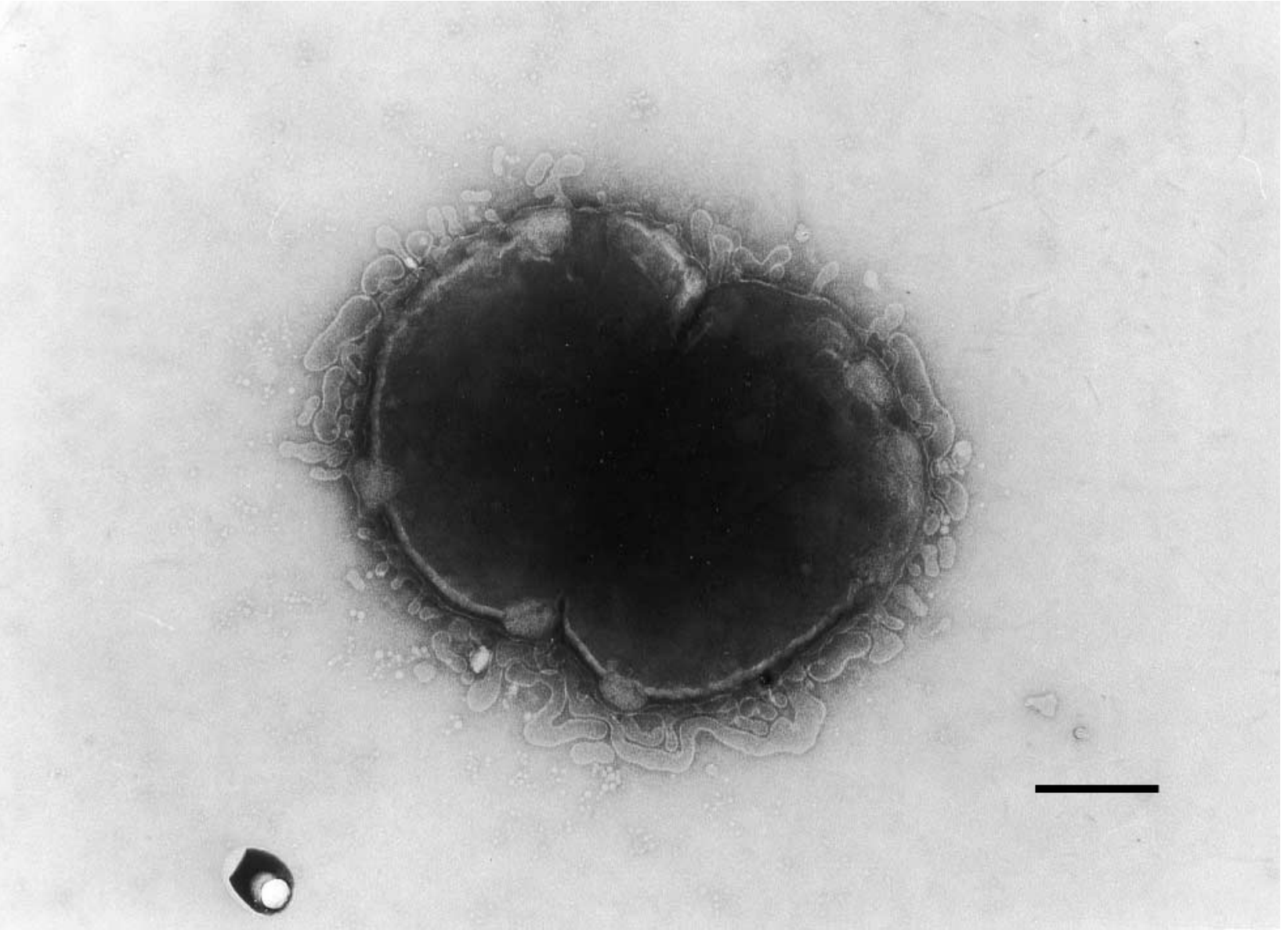

Fig. 1. Electron micrograph of a pair of meningococci showing blebbing of the outer membrane $(\times 70000$, bar, $0.2 \mu \mathrm{m})$.

Table 1. Cytokines, chemokines and effector molecules studied in MCD

\begin{tabular}{|c|c|c|c|c|c|c|}
\hline \multicolumn{2}{|l|}{ Cytokines } & \multicolumn{2}{|l|}{ Cytokine receptors } & \multirow[b]{2}{*}{ Interferons } & \multirow[b]{2}{*}{ Chemokines } & \multirow{2}{*}{$\begin{array}{l}\text { Colony stimulating } \\
\text { factors (CSF) }\end{array}$} \\
\hline Pro-inflammatory & Anti-inflammatory & Pro-inflammatory & Anti-inflammatory & & & \\
\hline $\begin{array}{l}\text { Tumour necrosis } \\
\text { factor- } \alpha \text { (TNF- } \alpha)\end{array}$ & $\begin{array}{l}\text { Interleukin-10 } \\
\text { (IL-10) }\end{array}$ & $\begin{array}{l}\text { Soluble IL-6 } \\
\text { receptor } \\
\text { (sIL-6R) }\end{array}$ & $\begin{array}{l}\text { TNF receptors R1 } \\
\text { and } 2 \\
\text { (TNF-R1 and } R 2 \text { ) }\end{array}$ & $\begin{array}{l}\text { Interferon- } \gamma \\
(\text { IFN- } \gamma \text { ) }\end{array}$ & $\begin{array}{l}\text { Interleukin-8 } \\
\text { (IL-8) }\end{array}$ & $\begin{array}{l}\text { Granulocyte-CSF } \\
\text { (G-CSF) }\end{array}$ \\
\hline $\begin{array}{l}\text { Interleukin-1 } \beta \\
(\mathrm{IL}-1 \beta)\end{array}$ & $\begin{array}{l}\text { IL-1 receptor } \\
\text { antagonist }\end{array}$ & & $\begin{array}{l}\text { IL-1 soluble } \\
\text { receptor type } 2 \\
\text { (IL-1sR2) }\end{array}$ & $\begin{array}{l}\text { Interferon- } \alpha \\
(\text { IFN- } \alpha)\end{array}$ & RANTES & $\begin{array}{l}\text { Granulocyte/ } \\
\text { macrophage-CSF } \\
\text { (GM-CSF) }\end{array}$ \\
\hline $\begin{array}{l}\text { Interleukin-2 } \\
\text { (IL-2) }\end{array}$ & $\begin{array}{l}\text { Interleukin-4 } \\
\text { (IL-4) }\end{array}$ & & & & $\begin{array}{l}\text { Macrophage } \\
\text { inflammatory } \\
\text { protein-1 } \alpha \\
\text { (MIP-1 } \alpha \text { ) }\end{array}$ & $\begin{array}{l}\text { Macrophage-CSF } \\
\text { (M-CSF) }\end{array}$ \\
\hline $\begin{array}{l}\text { Interleukin-6 } \\
\text { (IL-6) }\end{array}$ & & & & & $\begin{array}{l}\text { Macrophage } \\
\text { inflammatory } \\
\text { protein-1 } \beta \\
\text { (MIP-1 } \beta \text { ) }\end{array}$ & \\
\hline $\begin{array}{l}\text { Interleukin-12 } \\
\text { (IL-12) }\end{array}$ & & & & & $\begin{array}{l}\text { Monocyte } \\
\text { chemotactic } \\
\text { protein-1 } \\
\text { (MCP-1) }\end{array}$ & \\
\hline $\begin{array}{l}\text { Leukaemia/ } \\
\text { leucocyte } \\
\text { inhibitory factor } \\
\text { (LIF) }\end{array}$ & & & & & $\begin{array}{l}\text { Growth-related } \\
\text { gene } \\
\text { product- } \alpha \\
(\text { GRO- } \alpha)\end{array}$ & \\
\hline
\end{tabular}

molecule that mediates the interactions between virtually any cell lineages in an organism. Interleukins are molecules specifically involved in signalling between cells of the immune system; they are generally cytokines that have had their amino acid structure determined. Chemokines are molecules whose major function is chemo-attraction. Interferons are molecules that can confer on various cells a protective state against viruses and are also involved in signalling between cells of the immune system. Colony stimulat- 
ing factors are as they are named, but often also exhibit characteristics assigned to interleukins. For the purposes of this review, the term cytokine refers to a molecule that is not a chemokine, nor an interferon nor a colony stimulating factor.

A final point, before the data are assessed, is to consider whether studies employed immunoassays or bioassays, as these methods can give different results. Immunoassays include radioimmunoassay (RIA), enzyme-linked immunosorbent assay (ELISA), or a variation on this theme. ELISA is the preferred technique used latterly in research. ELISA measurement of cytokines has a detection limit ranging from 1 to $100 \mathrm{pg} / \mathrm{ml}$ (median $9 \mathrm{pg} / \mathrm{ml}$ ), but it cannot differentiate between the bioactive and bound inactive fractions in most cases. An exception to this is a commercial assay that is able to measure both biologically active as well as total transforming growth factor (TGF)- $\beta 1$ [6]. Bioassays assess the effect of serum or CSF on specific cell lines that will only proliferate or migrate in the presence of specific cytokines. The detection limits are broadly similar to those for immunoassays, ranging from 10 to 100 $\mathrm{pg} / \mathrm{ml}$. Some bioassays involve cytokine inhibition in a radioreceptor competition assay (RRA). It is unclear if these measurements correlate with cytokine activity [7]. Bioassays are less often used now, as they are far more labour intensive than ELISAs. A few studies have measured cytokine mRNA by in-situ hybridisation methods and the results generally correlate well with total cytokine levels [6].

The advantage of a bioassay over immunoassay is that only the active cytokine fraction is measured. There are minimal differences between the peak results in both assays, with both occurring at roughly the same time after infection or lipopolysaccharide (LPS) administration. The same is not true for recovery phase samples, with bioassay levels tending to return to normal more rapidly. Specific examples that illustrate these points are discussed in the sections covering tumour necrosis factor- $\alpha$ (TNF- $\alpha$ ), interleukin (IL)-1 and IL-6. Where it has not been stated, the method used was an immunoassay, usually ELISA.

\section{Cytokines}

\section{Pro-inflammatory}

$T N F-\alpha$. TNF- $\alpha$ is produced predominantly by $\mathrm{CD}^{+} \mathrm{T}$ cells and macrophages but also by neutrophils and has multiple, mainly pro-inflammatory actions. These include the activation of macrophages, granulocytes and cytotoxic cells, induction of leucocyte and endothelial adhesion molecules, induction of pyrexia, stimulation of acute phase proteins and enhanced major histocompatibility complex (MHC) class 1 expression. Through a variety of mechanisms it also acts to stimulate the pro-coagulant system. It is now realised that TNF- $\alpha$ is pivotal to the clinical manifestations in severe MCD. Early animal studies have shown that the administration of TNF- $\alpha$ to mice leads to many of the pathological changes seen in MCD and its inhibition prevents the mortality associated with gramnegative sepsis and LPS injection [8]. Synergy occurs if TNF- $\alpha$ is co-administered with IL-1. If given sequentially, at doses that would not normally induce any sequelae, then the pathological changes seen are more pronounced than if a single higher dose of either is given. The pathological effects include profound hypotension with a fall in systemic vascular resistance and central venous pressure and a concomitant increase in heart rate and cardiac output, with severe pulmonary oedema and haemorrhage. Prolonged administration results in leukopenia and thrombocytopenia. All of these effects are inhibited by prior administration of either of the cyclo-oxygenase inhibitors, ibuprofen or acetylsalicylic acid (aspirin) [9, 10].

TNF- $\alpha$ levels are raised in all patients with MCD. There is a significant positive correlation between TNF- $\alpha$ levels and severity scores, coagulopathies (including disseminated intravascular coagulation DIC) and outcome. TNF- $\alpha$ shows a significant negative correlation with C-reactive protein (CRP), leukopenia, thrombocytopenia and the interval between blood sampling and the appearance of petechiae. These associations are strongest in the patients who died [11-20]. Individual levels of the cytokines IL-1, IL-6, IL-8, IL-10 and IL-12 are all significantly positively correlated with TNF- $\alpha$ levels. This is also found with the inhibitory receptors of TNF- $\alpha$ and IL-1 (see later section). This increase in both pro- and anti-inflammatory cytokines indicates the generalised dysregulation in the inflammatory pathways seen in sepsis, which is particularly pronounced in MCD [18].

The kinetics of the release of TNF- $\alpha$ appear to be similar in both MCD and animal models of sepsis. In animals, maximal levels of TNF- $\alpha$ are reached by $1-$ $2 \mathrm{~h}$ after LPS injection but then fall rapidly and become undetectable by bioassays after 18-24 h [21]. ELISA techniques also demonstrate the rapid rise and fall in TNF- $\alpha$ levels; however, the difference is that persistently high levels are still detectable at $48 \mathrm{~h}$, but not at 7 days [22]. In patients with MCD, it is thought likely that cytokine pathways have been activated for a significant period before hospital admission, as patients have generally had symptoms for $12-24 \mathrm{~h}$ before seeking medical advice [22]. Therefore, the TNF- $\alpha$ level measured at presentation is probably not at its maximum but falling. Adults with sepsis also have elevated levels of TNF- $\alpha$, and these are significantly higher in infections caused by gram-negative bacteria [23]. Post-surgery intensive care patients with sepsis (not caused by $N$. meningitidis) do not show this pattern of TNF- $\alpha$ release. The rapid rise is usually seen only in fatal cases and levels remain elevated until death $[14,24]$. Patients with sepsis, with or without 
multi-organ failure, have levels maximal at days 7-9, which then slowly fall over 3 weeks [14]. High levels of TNF- $\alpha$ have also been found in cerebrospinal fluid (CSF) from patients with meningococcal meningitis (see later section on CSF cytokines).

TNF- $\alpha$ regulation occurs at both intracellular and extracellular levels. The extracellular regulation is via soluble TNF- $\alpha$ receptors (see later section). Intracellular regulation occurs at the post-transcriptional level. This is deduced from experiments with whole blood cultures, taken from patients with MCD that show no TNF- $\alpha$ production despite high TNF- $\alpha$ mRNA levels. In this study samples were obtained daily for 5 days and then subsequently stimulated with LPS. This showed that the production of TNF- $\alpha$ was suppressed initially, particularly in patients with septic shock, and then gradually returned to normal over the next 5 days. In the same samples, levels of TNF- $\alpha$ mRNA remained relatively static. However, due to the small number of patients in this study a pre-transcriptional regulatory effect cannot be fully excluded (in contrast see IL- $1 \beta$ regulation) [21]. Candidate cytokines that might regulate this effect include IL-10 and IL-6, which have been shown to inhibit TNF- $\alpha$ production in vitro [2527] and IFN- $\gamma$, which enhances TNF- $\alpha$ production without affecting mRNA levels [28]. In LPS-induced sepsis in mice, IL-10 administration resulted in a presumed pre-transcriptional down-regulation in TNF- $\alpha$ mRNA [29]. However, the prolonged underproduction of TNF- $\alpha$ in MCD cannot be accounted for solely by IL-10 or IL-6 inhibition, as their levels have returned to normal by days $2-3$.

Further clues to the regulation of TNF- $\alpha$ come from studies of gene polymorphisms. A bi-allelic polymorphism in the promoter region for the TNF- $\alpha$ gene, which may influence TNF- $\alpha$ production, has been described [30]. There are two allelic forms, TNF1 and TNF2, which are separated by a single base pair substitution at -308 nt. Possession of the TNF2 allele in MCD is associated with a significantly increased risk of severe disease and death. No differences are found between gene frequencies in patients and the general population [31]. These data imply that the possession of a TNF2 allele does not affect a patient's risk of developing MCD, but may influence disease severity. This mechanism of the genetic influence on TNF- $\alpha$ production has recently become less clear. TNF- $\alpha$ production following incubation with LPS is significantly lower in whole blood samples from relatives of non-survivors and survivors of MCD compared with samples from a control population [32]. In contrast to previous studies [20], the levels of TNF- $\alpha$ production were not associated with morbidity. Basal TNF- $\alpha$ levels were not significantly different between any groups. It is difficult to see how this new finding fits into the generally accepted picture of MCD. One explanation could be that these samples were stimulated with Escherichia coli-derived LPS, which has been shown to have c. 1000-fold less potency than $N$. meningitidis LOS. However, this is probably not the reason in this study, as LPS was administered at levels $>20000$ times that of the endotoxin levels measured in serum from patients with $\mathrm{MCD}(10000 \mathrm{ng} / \mathrm{ml}$ versus $0.5 \mathrm{ng} / \mathrm{ml})$ $[22,33]$. Another explanation would be the phenomenon of endotoxin tolerance. This is seen when mice are pre-exposed to either LPS or leukaemia inhibitory factor (LIF) and then re-challenged. The pre-treated animals show a significant reduction in mortality and TNF- $\alpha$ levels are lower compared with untreated animals $[34,35]$. It could be postulated that the relatives of patients with MCD have been exposed to $N$. meningitidis LPS or a related species previously and thus developed tolerance. This would not account for the increased severity of disease and mortality seen in the relatives of these patients. A theory that may explain some of the findings with TNF- $\alpha$ was put forward by Westendorp et al. [36]. They postulated that patients who develop severe disease do so because they initially produce an imbalance of pro- and antiinflammatory cytokines (low TNF- $\alpha$ and raised IL-10) that does not inhibit bacterial replication. Levels of pro-inflammatory cytokines, like TNF- $\alpha$, in children with severe MCD at the time of the initial infection, would be low and might either encourage bacterial growth or at least prevent its inhibition. The subsequent high levels measured at admission to hospital could be a secondary response to the resultant high bacterial load. A further recent study did not find any association between TNF gene polymorphisms and mortality [37]. The most plausible explanation for all these findings is probably that the polymorphism at $-308 \mathrm{nt}$ does not influence TNF- $\alpha$ production significantly. This is demonstrated by findings that in vitro, LPS-induced TNF- $\alpha$ production by monocytes is not influenced by either of the TNF1 or 2 genotypes [38].

$I L-1 \beta$. IL- 1 is produced predominantly by macrophages, endothelium and neutrophils. IL-1 shares many of its properties with TNF- $\alpha$ despite being structurally unrelated. These properties include increasing polymorphonuclear activity, up-regulation of endothelial adhesion molecules, induction of pro-coagulants, increased prostaglandin production, cytokine production and cytocidal activity by macrophages, increased $\mathrm{CD} 4^{+}$ T-cell proliferation and cytokine production and B-cell proliferation and differentiation towards antibody-forming cells (AFCs). IL- $1 \beta$ also acts as a chemotactic factor for neutrophils and macrophages. In animal models of sepsis, IL- $1 \beta$ and TNF- $\alpha$ have similar lethal effects and act synergically when co-administered. These include cardiovascular and haematological changes (see section on TNF- $\alpha$ ) [9]. IL- $\beta$ also appears to be directly stimulated by TNF- $\alpha$ in mouse sepsis models [39]. Lethality in experimental gram-negative sepsis is greatly reduced if IL- $1 \beta$ antagonists are administered before infection $[9,40]$. In MCD, high levels of IL-1 $\beta$ are significantly associated with poor 
outcome, severe shock and death $[11-13,41]$. In one study, levels were raised only in the cases that were rapidly fatal [17].

The kinetics of IL- $1 \beta$ production, measured by bioassay on sequential samples, are very similar to those of TNF- $\alpha$, but peak levels are not attained until 4-6 $\mathrm{h}$ after infection, with a rapid decrease to normal levels by $12-24 \mathrm{~h}$ [42]. In patients with shock due to MCD, levels measured by RIA fell rapidly to near normal by $24 \mathrm{~h}$, but then either persisted at this level or increased slightly [21, 41].

As with TNF- $\alpha$, IL- $1 \beta$ is regulated at the posttranscriptional level but, in contrast, pre-transcriptional regulation also occurs. This is again deduced from whole blood cultures stimulated with LPS, taken daily from patients with MCD, which showed a significant rise in IL- $1 \beta$ mRNA levels between the acute and the day 5 samples [21].

$I L-2$. IL-2 is mainly produced by activated $\mathrm{CD}^{+}{ }^{+} \mathrm{T}$ cells and to a lesser extent by $\mathrm{CD} 8^{+}$and natural killer (NK) cells. After T-cell stimulation, IL-2 mRNA becomes detectable by $4 \mathrm{~h}$, reaches a peak at $12 \mathrm{~h}$ and then falls rapidly. It also has a short serum half-life of $<30 \mathrm{~min}$, indicating that its principal action will be an autocrine one. It stimulates T-cell proliferation and interferon (IFN)- $\gamma$ release, B-cell growth, and macrophages and NK cells. It is released following T-cell interaction with antigen-presenting (APC) cells via the T-cell receptor and co-stimulatory molecules (e.g., B7, CD28).

Only one study has attempted to measure IL-2 in MCD with a bioassay and levels are undetectable in the serum of all patients, including those with shock [12].

IL-6. IL-6 is produced by various cells including T and $B$ cells, macrophages and fibroblasts. Its actions include the induction of acute phase proteins such as C-reactive protein (CRP) from the liver, increased proliferation and differentiation of $\mathrm{T}$ and $\mathrm{B}$ cells (the latter into AFCs), increased platelet formation, increased osteoblastic bone turnover and stimulation of pyrexia. In animal models, administration of recombinant IL- 6 causes pyrexia, but there is no increase in the acute toxic effects or mortality that are seen with TNF$\alpha$ and IL-1 administration [43]. Further experiments have shown that TNF- $\alpha$ acts as a positive regulator of IL-6 [39], whereas IL-6 may act as a negative regulator of TNF- $\alpha$ [27].

As with the cytokines already described, IL-6 is raised in MCD, with the highest levels being found in patients with shock and especially those who died [12, 1719,44-46]. Similar results have also been found in adults with sepsis [23].

The kinetics of IL-6 release in MCD are very similar to those of TNF- $\alpha$ and IL- $1 \beta$, peaking early and then falling rapidly. The peak occurs later than for TNF- $\alpha$ and IL- $1 \beta$, at about $6-8 \mathrm{~h}$. The fall is not as precipitous, reducing to normal levels over $36 \mathrm{~h}$ when measured by bioassay [12]. However, in adult sepsis, levels are still elevated in some patients at $72 \mathrm{~h}$ [47]. Immunoassay with an ELISA method detected IL- 6 in serum for up to $100 \mathrm{~h}$, especially in those with severe shock $[22,45]$.

IL-12. IL-12 p70 is a heterodimer consisting of two subunits (p40 and p35) and is produced by monocytes/ macrophages and $\mathrm{T}$ cells. Its precise role in vivo is not known but it has a central role in the maturation of naive $\mathrm{CD}^{+} \mathrm{T}$ cells towards IFN- $\gamma$-producing Th1 $\mathrm{T}$ cells and inhibits Th2 T cells. Therefore, this would focus the immune response away from antibody production towards IFN- $\gamma$ stimulation of macrophages. IFN- $\gamma$ also stimulates monocytes to produce IL-12 p40, primes them to express p35 on LPS stimulation and may, therefore, act by a positive feedback mechanism [48]. IL-12 also enhances NK cell activity and cytotoxic lymphocyte function [49].

In children with meningococcal shock, the p40 subunit is elevated in all groups and found to be significantly higher in non-survivors compared with survivors. In contrast, the p70 heterodimer is raised in only $19 \%$ of patients. Where it is raised, p40 levels are significantly higher. Levels of the p40 subunit are positively correlated with levels of TNF- $\alpha$, IL-6, IL-8, IL-10 and the Paediatric Risk of Mortality (PRISM) score and are negatively correlated to $\mathrm{CRP}$, admission glucose levels and white blood cell counts. Patients with elevated levels of p70 have significantly raised IL-8. Furthermore, $29 \%$ of patients have detectable IFN- $\gamma$ levels and these patients have significantly raised levels of IL-6, IL-8 and IL-10 but not IL-12 p40 [50]. Whilst it has been demonstrated that IL-12 p40 levels are associated with outcome, the lack of correlation with its principal stimulant IFN- $\gamma$ is difficult to understand. One explanation could be that they are released sequentially and not simultaneously, whilst another is that some IL-12 production could be IFN- $\gamma$ independent, as is seen in an IFN- $\gamma$ knockout mouse model [51].

Leukaemia/leucocyte inhibitory factor (LIF). Fibroblasts, endothelial cells and activated lymphocytes and macrophages all produce LIF. Its properties include the regulation of acute phase proteins, myeloid cell differentiation and a possible influence on cardiac contractility [52].

High LIF levels measured by radioreceptor competition assay (RRA) at $12 \mathrm{~h}$ after admission correlate significantly with disease severity and outcome in MCD. Levels are undetectable by $36 \mathrm{~h}$ [7]. These data are similar to those found in adults with sepsis, although not all studies show significantly raised LIF levels 
[23, 53-55]. Animal models of E. coli-induced sepsis revealed raised LIF levels. In baboons, this is reduced by pre-treatment with an anti-TNF- $\alpha$ antibody [23]. In mice with $E$. coli-induced sepsis, continuous infusions of LIF increased mortality, but treatment with LIF before the infection markedly reduced mortality. This result resembles endotoxin tolerance and is characterised by the suppression of $E$. coli-induced TNF- $\alpha$, a reduction in the number of viable bacteria from blood and organ cultures and prevention of sepsis-induced tissue injury [35]. These observations suggest that systemic LIF production is part of the complex host response to both endotoxin and sepsis-induced tissue injury.

Summary - pro-inflammatory cytokines. In summary, the pro-inflammatory cytokines discussed have complex interactions in MCD. The main causes of the sequelae in MCD are probably elevated levels of TNF$\alpha$ and IL- 1 in serum and thus in the tissues. The animal experimental data above strongly support this proposition, but direct evidence of anything other than an association between cytokine levels and the sequelae seen in MCD in man does not exist. Future studies in man on gene polymorphisms may shed some light on this, but as with the TNF- $\alpha$ data, may give conflicting results.

\section{Anti-inflammatory}

$I L-10$. IL-10 is produced by $\mathrm{CD}^{+} \mathrm{Th} 2 \mathrm{~T}$ cells and macrophages. It is a potent inhibitor of Th1 T-cell cytokines and LPS-activated macrophage cytokines (monokines) such as TNF- $\alpha$, IL-1, IL-6, IL-8 and GM-CSF [29, 56, 57]. In vitro, it acts by downregulating macrophage $\mathrm{MHC}$ class 2 receptors and also acts in an auto-regulatory manner by inhibiting IL-10 mRNA synthesis [58]. In mice challenged with LPS, low-dose recombinant IL-10 inhibited the release of IFN- $\gamma$ and TNF- $\alpha$ and at higher doses completely prevented lethality $[25,26,59]$.

IL-10 is significantly raised in children with MCD, particularly in fatal cases. It is also positively correlated with endotoxin, TNF- $\alpha$, IL-6, IL-8, soluble TNF- $\alpha$ receptors (sTNFR) levels and severity scores $[17,18,60-62]$. IL-10 has also been found in CSF in bacterial meningitis [63] (see later section). It has been shown to be the cytokine in the serum of patients with MCD that inhibits the induction of monocytes/macrophages by LPS [58]. It also inhibits the pro-coagulant activity induced on the surface of monocytes/macrophages by LPS [64]. The elevated levels of IL-10 in MCD may represent the generally increased activity of the majority of cytokines, both pro- and anti-inflammatory. In severe disease the effects of the antiinflammatory cytokines are probably over-ridden by the pro-inflammatory cytokines. However, data from Westendorp et al. show that IL-10 production is independent of the pro-inflammatory cytokine TNF- $\alpha$ [32].
IL-4. IL-4, like IL-10, is produced mainly by $\mathrm{CD} 4^{+}$ Th2 T cells and shares many of the properties of IL- 10 . These include the potent inhibition of monokines. Despite these shared properties, no studies have been able to detect raised levels of IL-4 in any patients with MCD [17, 57, 65-67].

\section{Cytokine receptors}

\section{Pro-inflammatory}

Soluble IL-6 receptor (sIL-6R). Soluble IL-6R is shed or secreted from many cell types including macrophages, hepatocytes, $\mathrm{T}$ cells and plasma cells. It couples with IL-6 and then leads to increased IL-6mediated signal transduction and acute phase protein production. Mice without sIL-6R show very little innate IL-6 activity, but this can be re-instated by sIL-6R administration [68]. In acute MCD, levels of sIL-6R in serum are negatively correlated with disease severity and rise slowly over the next 5 days. This is thought to act as a control mechanism, preventing overstimulation of the cytokine cascade by IL-6. These results did not reach statistical significance due to the small sample sizes $[45,46]$, but a similar pattern of high IL-6 and low sIL-6R is seen in adults with gramnegative and gram-positive sepsis $[69,70]$. Plasmapheresis, sometimes used to remove cytokines in severe sepsis, interestingly leads to an increase in sIL-6R levels, albeit transiently. The effect of this on disease outcome has not yet been formally studied [45].

\section{Anti-inflammatory}

TNF receptor (TNF-R1 and 2). The TNF receptor is a naturally occurring antagonist for the actions of TNF- $\alpha$ that is also found free in serum as soluble TNF-R (sTNF-R). There are two forms, TNF-R1 and TNF-R2 (or TNFsR p55 and p75 respectively), which are released predominantly from macrophages and endothelium [71]. Both of these are raised in MCD [15-18]. In survivors of MCD, the increase in levels of TNFsR p55 and p75 is proportional to TNF- $\alpha$ (for TNF- $\alpha$ levels $<500 \mathrm{pg} / \mathrm{ml}$ ). However, for TNF- $\alpha$ levels $>500 \mathrm{pg} / \mathrm{ml}$, particularly in patients who died, this relationship no longer exists, as TNF- $\alpha$ production far exceeds the secretion of either of the receptors [15]. TNF- $\alpha$ levels fell rapidly as stated above and therefore did not differentiate between shock and non-shock patients at $6 \mathrm{~h}$ [15]. However, both TNFsR p55 and p75 levels, despite decreasing significantly over the first $24 \mathrm{~h}$, still remained raised above the normal range for 6 days after infection and differentiated between shock and non-shock patients at this stage [16]. Plasmapheresis, which produced a rise in serum sIL-6R in MCD, resulted in a fall in both TNF-R1 and TNF-R2 levels and as with sIL-6R, this effect is transient.

$I L-1$ receptor antagonists (IL-1Ra and $I L-1 s R 2)$. As with TNF- $\alpha$, IL- $1 \beta$ has two antagonists, IL-1 receptor 
antagonist (IL-1Ra/IL-1ra) and IL-1 soluble receptor type 2 (IL-1sR2). Both can occur in a soluble state and antagonise the actions of IL- $1 \beta$. IL-1Ra is a misnomer as it is in fact not a receptor, but it is a cytokine that binds to the IL- $1 \beta$ receptor, inhibits the binding of IL$1 \beta$ and prevents signal transduction. Both IL-1Ra and IL-1sR2 are raised in MCD but have different properties. IL-1Ra shows similar characteristics to other cytokines studied. It peaks at the time of admission and then falls steeply over $48 \mathrm{~h}$ with a sustained phase of modestly elevated levels that persists for up to 6 days $[41,72]$. IL-1sR2, in contrast, is raised in both shock and non-shock patients at admission and levels then rise during the recovery phase [41]. This increase is more significant in the shocked patients and reaches a maximum at 3-5 days after admission. The differences between the kinetics of IL-1Ra and IL-1sR2 production would result in an overlapping and thus longer period of antagonism of IL- $1 \beta$ : as antagonism by IL-1Ra decreases it would be replaced by the actions of increasing levels of IL-1sR2.

The elevated receptor antagonist levels found in the serum of patients with MCD, like the increase in IL-10, probably reflect general stimulation of the cytokine cascade. In normal situations their inhibitory effects would probably balance out the stimulatory effects of IL-1, but in severe MCD this balance is not maintained.

\section{Interferons (IFN)}

$I F N-\gamma$

IFN- $\gamma$ is produced by $\mathrm{T}$ cells, NK cells and activated monocytes [73]. Its multiple actions include induction of the MHC classes 1 and 2, macrophage activation and increased expression of lymphocyte and endothelial cell adhesion molecules. With TNF- $\alpha$ as the trigger it also increases nitric oxide (NO) production by neutrophils, macrophages and endothelium. Animal studies of LPS lethality in mice have shown that IFN- $\gamma$ plays a more significant role than TNF- $\alpha$, as anti-IFN- $\gamma$ but not anti-TNF- $\alpha$ antibodies significantly reduce mortality. Administration of recombinant IFN- $\gamma$ to these mice increased LPS lethality, especially if given concomitantly with TNF- $\alpha[10,74,75]$. It also induced TNF- $\alpha$ production when administered before LPS injection [28].

High levels of IFN- $\gamma$ were found in patients with MCD who did not survive [13]. In a different study, 29\% of patients with septic shock and purpura (MCD) had elevated IFN- $\gamma$ levels. These patients had significantly higher IL-6, IL-8 and IL-10 but not IL-12 p40 levels, higher lactate levels and lower white blood cell counts [50]. Elevated IFN- $\gamma$ levels have not been demonstrated in all studies of MCD [12] nor in adults with septic shock [24]. The elevated levels of IL-10 demonstrated in MCD are of interest, as IL-10 inhibits IFN- $\gamma$ production in vitro [26].

\section{$I F N-\alpha$}

IFN- $\alpha$ production can be induced in the majority of cells and is involved primarily in host defence against viral pathogens by arresting cell development and increasing MHC class I expression. Not surprisingly, therefore, no differences have been found between IFN$\alpha$ levels in survivors and non-survivors with MCD [13] and in adults with sepsis [24].

\section{Chemokines}

There are few data on serum chemokines in meningococcal sepsis, but more has been described for patients with meningitis (see CSF section later).

\section{IL-8}

IL- 8 is produced by macrophages and endothelial cells and is chemotactic mainly for neutrophils, in which it stimulates adhesion and degranulation. High IL-8 levels are associated with poor outcome as with other markers of inflammation in MCD $[18,44,61]$ and in adults with sepsis [23]. Levels were highest in the group that had symptoms for $<12 \mathrm{~h}$ before admission. In the few patients studied $(n=5)$ levels fell rapidly and were not measurable by $3-16 \mathrm{~h}$, thus mirroring TNF- $\alpha$, IL- 1 and IL-6 kinetics [76].

\section{Released on activation normal T-cell expressed and secreted (RANTES)}

RANTES is produced mainly by activated $\mathrm{T}$ cells (as its name implies) and also by somatic cells. It acts as a chemo-attractant to $\mathrm{T}$ cells and macrophages as well as basophils, mast cells and dendritic (antigen-presenting) cells. It also activates $\mathrm{T}$ cells and up-regulates cellular adhesion molecules on antigen-presenting cells. Recent data from children with MCD have shown that levels of RANTES have an inverse relationship to outcome and severity. This inverse relationship with any cytokine/ chemokine in MCD or sepsis has not been documented previously [77].

\section{Colony stimulating factors}

The colony stimulating factors include granulocyte (G$\mathrm{CSF}$ ), granulocyte-macrophage (GM-CSF) and macrophage (M-CSF) colony stimulating factors. They are produced by monocytes/macrophages, lymphocytes, fibroblasts and endothelial cells. They have many roles, including the proliferation, differentiation and maturation of polymorphonuclear and mononuclear phagocytic progenitors. G-CSF and GM-CSF also enhance effector functions of mature neutrophils, such as adhesion to vascular endothelium, phagocytosis and 
microbial killing, chemotaxis and superoxide production. Macrophages differentiated by GM-CSF have an improved antigen-presenting capacity that can be explained by an increase in MHC class 2 protein expression. All colony stimulating factors increase the defence response of the host against microbial infection. The kinetics of production of these three factors in MCD are markedly different.

Plasma G-CSF is raised, but only briefly, in early MCD, with higher levels found in patients with shock and those who died. Levels return to normal within 1-7 days. High levels of G-CSF are also found in adults with sepsis [23]. GM-CSF levels, in contrast, are only raised in patients with life-threatening or fulminant septic shock and in the patients who survive fall to undetectable levels by $8-12 \mathrm{~h}$. M-CSF is marginally raised in all patients but is not significantly associated with any specific outcome. In the small number of patients who had sequential samples taken the levels remained essentially unchanged [78].

\section{Other effector molecules}

\section{Nitric oxide (NO)}

NO is produced from arginine by NO synthase (both constitutive and inducible) and controls vascular tone in healthy individuals. However, during sepsis, an excess of NO is produced by macrophages and neutrophils following stimulation by TNF- $\alpha$, IFN- $\gamma$ and LPS $[73,79,80]$. This excess NO combines with oxygen radicals to form peroxynitrite (ONOO'), a molecule that is bactericidal, but can also be harmful to host tissues. The effects of this excess NO include reduced vascular resistance, with a reduction in the systemic and pulmonary blood pressures. This is reversed following the administration of NO synthase inhibitors. The myocardial dysfunction, increased oxygen consumption and the increase in endothelial permeability seen in septic patients are all partly attributable to the excess of NO [81-84]. Significantly higher levels of $\mathrm{NO}$ are associated with severe disease or a GMSPS $>8$ in children with MCD [85] and hypotension in children with septic shock due to various causes [86].

\section{Tissue factors}

Tissue thromboplastin is a tissue factor that stimulates the extrinsic coagulation cascade. Its expression on monocytes/macrophages and endothelial cell lines can be increased by stimulation with LPS, IL-1 or TNF- $\alpha$. Increased tissue thromboplastin levels (60-300-fold) are associated with a worse outcome in patients with MCD [87].

Transforming growth factor- $\beta$ (TGF- $\beta$ ) produced by $\mathrm{T}$ and $\mathrm{B}$ cells, macrophages and platelets is a potent inhibitor of T-cell proliferation, Th1 lymphokines and monokines. It has been undetectable in the serum of patients with MCD [57] (but see CSF section later).

\section{Fibronectin}

Fibronectin is synthesised by a variety of cells including macrophages, fibroblasts and endothelial cells, but its regulation is poorly understood. It is an inflammatory mediator, found in cryoprecipitate, which appears to act as an opsonin and aid phagocytosis. It also stimulates platelet aggregation and the clotting cascade in DIC. In sepsis, it is generally lower in grampositive than gram-negative infections $[88,89]$. The levels are not consistently low, probably due to the difference in times between the onset of the infection and presentation.

In MCD, fibronectin is inversely correlated with high IL-6 levels and is significantly elevated in those patients who die or have clinical signs of shock [9092]. In animal models of sepsis, fibronectin therapy has produced a reduction in mortality, but it has not yet been evaluated in MCD.

\section{Plasminogen activator inhibitor (PAI-1)}

PAI-1 is an inhibitor of fibrinolysis and is released from platelets and endothelial cells after stimulation by various cytokines, particularly TNF- $\alpha$. It combines with tissue and urinary plasminogen activators and protein $\mathrm{C}$ to inhibit fibrinolysis. Higher levels of PAI-1 are found in non-survivors compared with survivors of MCD and are also significantly associated with TNF- $\alpha$, IL-6, IL-8 and IL-10 levels in these patients [18, 72, 93]. A gene polymorphism that predisposes to increased PAI-1 levels is associated with poorer outcomes in MCD. The homozygote $4 \mathrm{G} / 4 \mathrm{G}$ polymorphism is significantly associated with higher PAI-1 levels and death especially in the sepsis group [93]. The frequencies of the $4 \mathrm{G}$ and $5 \mathrm{G}$ alleles in patients with MCD compared to controls are identical (53\% versus 47\%). However, analysis of the genotypes of the relatives of patients, both survivors and non-survivors, revealed that the 4G/ $4 \mathrm{G}$ genotype occurs with a greater frequency in relatives of patients with septic shock (36\%) compared with relatives of patients with meningitis $(9 \%)$. In contrast the $5 \mathrm{G} / 5 \mathrm{G}$ genotype is significantly commoner amongst relatives of patients with meningitis $(31 \%)$ compared with relatives of patients with septic shock $(11 \%)$. The frequency of the $4 \mathrm{G}$ and $5 \mathrm{G}$ alleles is the same in relatives of non-survivors and survivors $(28 \%$ versus $26 \%$ ). Deaths occur predominantly in the septic shock group, but the 4G/4G genotype occurred with a comparable frequency in both groups $(26 \%$ survivors versus $28 \%$ non-survivors). These results suggest that PAI-1 gene polymorphisms do not influence the risk of developing MCD, but may have an influence on whether the presentation is predominantly septic shock or meningitis [94]. 


\section{Cerebrospinal fluid (CSF)}

Meningitis does not usually occur in isolation from septicaemia/bacteraemia, but is usually one end of a spectrum of disease. The cytokines discussed earlier have been investigated generally in the clinical context of septicaemia and shock. When meningitis forms the major clinical picture, the outcomes are markedly different from those seen with sepsis $[2,95]$. The cytokines and chemokines that have been studied in both CSF and serum from patients with meningitis are usually localised to the CSF with little evidence of a systemic inflammatory response.

\section{Cytokines and receptors}

As stated above, CSF cytokine levels in meningitis do not generally correlate with those found in serum. In studies in which the majority of patients have meningococcal meningitis, IL-1, IL-6, IL-10, TNF- $\alpha$, sTNFR1 and 2, IL-1Ra and IL-1sR2 are all significantly raised in CSF samples [17, 41, 42, 63, 76]. CSF levels of IL-1, IL-6, TNF- $\alpha$ and sTNFR1 and 2 in patients with meningococcal sepsis without meningitis are less commonly raised, with high levels generally found only in the patients who died $[17,42]$. Only CSF IL-6 levels show a significant correlation with the CSF white cell counts [42]. CSF from patients with other forms of meningitis also show high initial levels of the cytokines IL- $1 \beta$ and TNF- $\alpha$, as well as TGF- $\beta[6,11,96]$. TNF- $\alpha$ and TGF- $\beta$, measured by in-situ hybridisation, are shown to originate from neutrophils early in the acute phase and from lymphocytes and monocytes during the convalescent phase $[6,96]$. In mouse experiments in which LPS was injected into the subarachnoid space, TNF- $\alpha$ and IL-1 levels peaked at 2 and $3 \mathrm{~h}$, respectively, and then fell rapidly to near normal levels by $8 \mathrm{~h}$. Similar effects are seen with IL-6, but the peak is smaller and occurs at $3 \mathrm{~h}$. These kinetics closely mirror those seen in serum samples from patients with MCD. Leucocyte counts and protein levels also increase but more steadily, reaching a peak at $8-10 \mathrm{~h}$ and then slowly falling over the next $24 \mathrm{~h}$ [42].

\section{Chemokines}

IL-8 is the only chemokine that has been measured in CSF samples from patients with MCD [76]. Other chemokines have been measured only in CSF from patients with bacterial meningitis of multiple aetiologies. In a single study there was no difference between the chemokine levels from patients with meningococcal meningitis and those with Haemophilus influenzae or Streptococcus pneumoniae meningitis [97]. Patients with meningitis caused by various pathogens have significantly higher CSF levels of the chemokines IL-8, growth-related gene product- $\alpha$ (GRO- $\alpha)$, macrophage inflammatory protein- $\beta$ (MIP-1 $\beta$ ) and monocyte chemotactic protein-1 (MCP-1) but not RANTES compared with febrile non-meningitis controls. MIP-
$1 \alpha$ is variably raised. The individual chemokine levels correlate significantly with a leucocyte chemotaxis bioassay. Chemokine levels and chemotactic activity are not associated with CSF laboratory features including cell counts [98]. The majority of studies show no correlation between chemokine levels and CSF cell numbers or populations [76, 97, 98]. However, a single study demonstrated that IL- 8 and GRO- $\alpha$ levels did correlate with granulocyte counts and MCP-1 levels with monocyte counts. This study did not give details of the causative organisms identified [99].

There is no demonstrable association between chemokine levels in CSF and in parallel serum samples. In most serum samples, chemokine levels are undetectable, indicating that the chemokines detected in CSF have originated from cells in the CSF [97, 99].

\section{Other molecules studied}

In meningococcal meningitis, levels of NO are higher in CSF than in serum and higher when compared with controls, indicating the local production of NO [100]. The function of NO in meningitis has yet to be elucidated, but it is known to be neurotoxic at high levels [101].

Prostaglandin E2 and I2 levels are detectable in CSF in $90 \%$ and $56 \%$ of cases of meningitis, respectively. They are significantly associated with CSF IL-1, protein, lactate and white blood cell levels and show a significant reduction following treatment with dexamethasone in comparison with controls. The aetiology of meningitis in $90 \%$ of the patients in this group was $H$. influenzae type $\mathrm{b}$, with infection in the remaining $10 \%$ of patients accounted for by $N$. meningitidis and S. pneumoniae [11].

\section{Areas of further study}

The gaps in current knowledge that need to be filled to increase our understanding of the events in septic shock include the roles of interleukins such as IL-2, IL-3, IL-13 and IL-18, TGF- $\beta$ and macrophage cytokines (monokines) and their interactions with other molecules including macrophage migration inhibitory factor (MIF). The DNA transcription proteins such as high mobility group-1 (HMG-1) are not cytokines but appear to have similar actions. In mice, their inhibition prevents LPS-induced mortality even if administration is delayed for up to $24 \mathrm{~h}$ after inoculation [102]. This has not been described before with conventional cytokines.

Confirmation of the direct role of each specific cytokine in MCD is difficult to demonstrate. Indirect evidence may be demonstrated by a reduction in cytokine levels or in the effector molecule(s) on which the cytokine acts when specific inflammatory modula- 


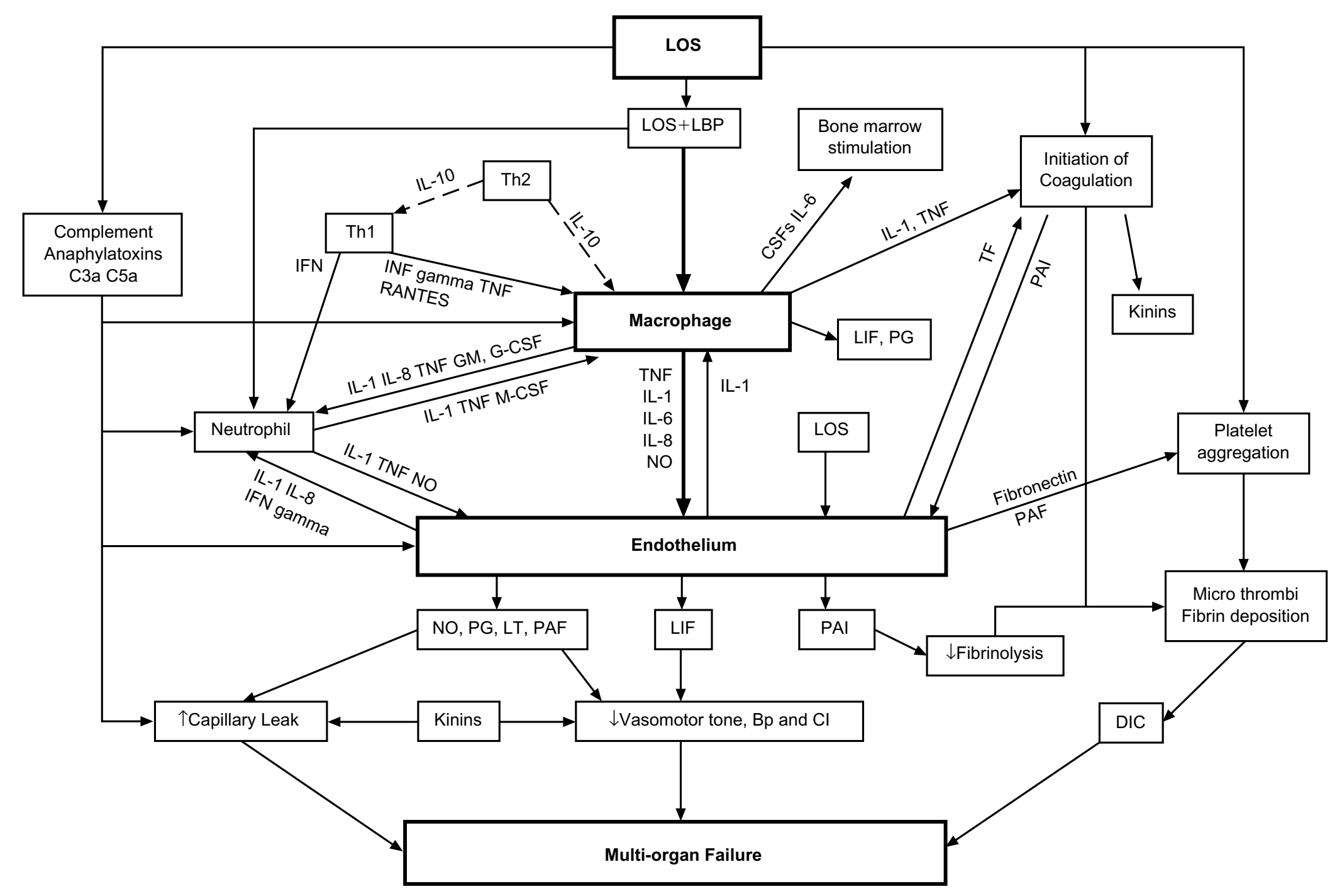

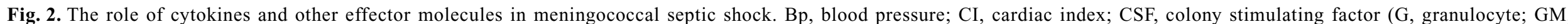

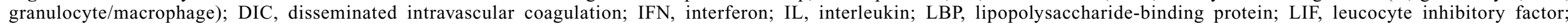

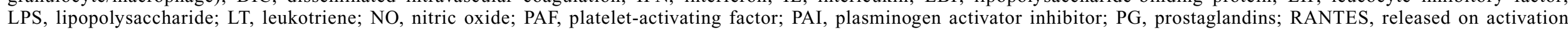

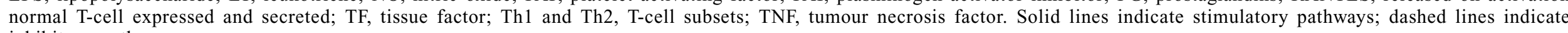
inhibitory pathways. 
tors are administered to these patients. An alteration in clinical outcome may also be noted.

\section{Conclusions}

There are significant differences between cytokine and chemokine levels in experimental models of sepsis and MCD. These differences are not irreconcilable and in some cases are probably due to the complex interaction between all the molecules and cell lineages in vivo that could never be replicated in vitro. Encouragingly, the majority of cytokines, interferons, chemokines and other effector molecules that have been studied in paediatric MCD appear to have similar functions and kinetics and occur broadly at the same levels as in adults with sepsis.

The onset of MCD is relatively easy to define and the clinical condition is usually easy to diagnose. Therefore, MCD is a less complicated model in which to study cytokine function in sepsis compared with adult sepsis syndromes. The latter are generally very heterogeneous, they include multiple causative organisms and also have a high percentage of microbiologically unproven infections.

This relative consistency in diagnosis and clinical symptoms and signs means that a search for potential targets of therapy is likely to be more fruitful in MCD. Studies into anti-cytokine therapies in sepsis are easier to conduct and probably more likely to show a significant result in patients with MCD. However, this goal has yet to be achieved due to a number of factors, including an incomplete understanding of the inflammatory cascade and how the biochemical markers relate to clinical outcomes in sepsis. For example, TNF- $\alpha$ is probably a major cause of pathology in MCD and, as stated previously, higher levels are found in the more severely affected patients. High levels of IL-10 are also found in non-survivors, but this is probably a sign of activation of the inhibitory cytokine cascade. A further major step in our understanding will be achieved when we are able to correlate measured cytokine levels with their true functional levels.

Fig. 2 attempts to show how the current knowledge of cytokines and effector molecules in MCD fits into the generally accepted stages of septic shock, from the initiation of the cytokine cascade by LOS to cellular activation and ultimately to specific sequelae. This is a simplified, far from complete picture, with many of the steps still poorly understood. Attempts to fill these gaps in our knowledge would give us a better understanding of the inflammatory cascade in sepsis and could lead to insights into new therapies.

We thank Dr J. McLaughlin for his advice on an earlier draft of this paper. We also thank the Meningitis Research Foundation for their financial support for this work.

\section{References}

1. Kirsch EA, Barton RP, Kitchen L, Giroir BP. Pathophysiology, treatment and outcome of meningococcemia: a review and recent experience. Pediatr Infect Dis J 1996; 15: 967-978.

2. Riordan FA, Marzouk O, Thomson AP, Sills JA, Hart CA. The changing presentations of meningococcal disease. Eur $J$ Pediatr 1995; 154: 472-474.

3. Moore PS. Meningococcal meningitis in sub-Saharan Africa: a model for the epidemic process. Clin Infect Dis 1992; 14: 515-525.

4. Wyllie D, Pridmore A, Steeghs L, van der Ley P, Dower S, Read R. Potent stimulation of human macrophages by lipopolysaccharide-deficient Neisseria meningitidis. In: Proceedings of the Federation of Infection Societies Conference, Manchester. 2000.

5. Uronen H, Williams AJ, Dixon $\mathrm{G}$ et al. Gram-negative bacteria induce pro-inflammatory cytokine production by monocytes in the absence of lipopolysaccharide (LPS). Clin Exp Immunol 2000; 122: 312-315.

6. Ossege LM, Sindern E, Voss B, Malin JP. Expression of tumor necrosis factor-alpha and transforming growth factorbeta 1 in cerebrospinal fluid cells in meningitis. J Neurol Sci 1996; 144: 1-13.

7. Waring PM, Waring LJ, Metcalf D. Circulating leukemia inhibitory factor levels correlate with disease severity in meningococcemia. J Infect Dis 1994; 170: 1224-1228.

8. Nassif X, Mathison JC, Wolfson E, Koziol JA, Ulevitch RJ, So M. Tumour necrosis factor alpha antibody protects against lethal meningococcaemia. Mol Microbiol 1992; 6: 591-597.

9. Okusawa S, Gelfand JA, Ikejima T, Connolly RJ, Dinarello CA. Interleukin 1 induces a shock-like state in rabbits. Synergism with tumor necrosis factor and the effect of cyclooxygenase inhibition. $J$ Clin Invest 1988; 81: $1162-1172$.

10. Talmadge JE, Bowersox O, Tribble H, Lee SH, Shepard HM, Liggitt D. Toxicity of tumor necrosis factor is synergistic with gamma-interferon and can be reduced with cyclooxygenase inhibitors. Am J Pathol 1987; 128: 410-425.

11. Mustafa MM, Ramilo O, Saez-Llorens X, Mertsola J, Magness RR, McCracken GH. Prostaglandins E2 and I2, interleukin 1-beta, and tumor necrosis factor in cerebrospinal fluid in infants and children with bacterial meningitis. Pediatr Infect Dis J 1989; 8: 921-922.

12. Waage A, Brandtzaeg P, Halstensen A, Kierulf P, Espevik T. The complex pattern of cytokines in serum from patients with meningococcal septic shock. Association between interleukin 6, interleukin 1, and fatal outcome. J Exp Med 1989; 169: 333-338.

13. Girardin E, Grau GE, Dayer J-M, Roux-Lombard P, Lambert $\mathrm{PH}$, the J5 Study Group. Tumor necrosis factor and interleukin-1 in the serum of children with severe infectious purpura. N Engl J Med 1988; 319: 397-400.

14. Waage A, Aasen AO. Different role of cytokine mediators in septic shock related to meningococcal disease and surgery/ polytrauma. Immunol Rev 1992; 127: 221-230.

15. Girardin E, Roux-Lombard P, Grau GE, Suter P, Gallati H, the J5 Study Group. Imbalance between tumour necrosis factor-alpha and soluble TNF receptor concentrations in severe meningococcaemia. Immunology 1992; 76: 20-23.

16. van Deuren M, Frieling JTM, van der Ven-Jongekrijg J et al. Plasma patterns of tumor necrosis factor-alpha (TNF) and TNF soluble receptors during acute meningococcal infections and the effect of plasma exchange. Clin Infect Dis 1998; 26: 918-923.

17. van Deuren $M$, van der Ven-Jongekrijg J, Bartelink AK, van Dalen R, Sauerwein RW, van der Meer JWM. Correlation between proinflammatory cytokines and antiinflammatory mediators and the severity of disease in meningococcal infections. J Infect Dis 1995; 172: 433-439.

18. Kornelisse RF, Hazelzet JA, Savelkoul HF et al. The relationship between plasminogen activator inhibitor-1 and proinflammatory and counterinflammatory mediators in children with meningococcal septic shock. J Infect Dis 1996; 173: $1148-1156$.

19. Romijn JA, Godfried MH, Wortel C, Sauerwein HP. Hypoglycemia, hormones and cytokines in fatal meningococcal septicemia. J Endocrinol Invest 1990; 13: 743-747.

20. Westendorp RG, Langermans JAM, de Bel CE et al. Release 
of tumor necrosis factor: an innate host characteristic that may contribute to the outcome of meningococcal disease. $J$ Infect Dis 1995; 171: 1057-1060.

21. van Deuren M, Netea MG, Hijmans A et al. Posttranscriptional down-regulation of tumor necrosis factor-alpha and interleukin-1beta production in acute meningococcal infections. J Infect Dis 1998; 177: 1401-1405.

22. Marzouk O. Clinical and laboratory aspects of meningococcal disease in childhood. MD Thesis, Liverpool University. 1994.

23. Kragsbjerg P, Holmberg H, Vikerfors T. Dynamics of blood cytokine concentrations in patients with bacteremic infections. Scand J Infect Dis 1996; 28: 391-398.

24. Calandra T, Baumgartner JD, Grau GE et al. Prognostic values of tumor necrosis factor/cachectin, interleukin-1, interferon-alpha, and interferon-gamma in the serum of patients with septic shock. Swiss-Dutch J5 Immunoglobulin Study Group. J Infect Dis 1990; 161: 982-987.

25. Gérard C, Bruyns C, Marchant A et al. Interleukin 10 reduces the release of tumor necrosis factor and prevents lethality in experimental endotoxemia. J Exp Med 1993; 177: 547-550.

26. Marchant A, Bruyns C, Vandenabeele $\mathrm{P}$ et al. Interleukin-10 controls interferon-gamma and tumor necrosis factor production during experimental endotoxemia. Eur J Immunol 1994; 24: $1167-1171$

27. Bucklin SE, Silverstein R, Morrison DC. An interleukin-6induced acute-phase response does not confer protection against lipopolysaccharide lethality. Infect Immun 1993; 61: 3184-3189.

28. Heinzel FP. The role of IFN-gamma in the pathology of experimental endotoxemia. J Immunol 1990; 145: 2920-2924.

29. Fiorentino DF, Zlotnik A, Mosmann TR, Howard M, O'Garra A. IL-10 inhibits cytokine production by activated macrophages. J Immunol 1991; 147: 3815-3822.

30. Wilson AG, de Vries N, Pociot F, di Giovine FS, van der Putte LBA, Duff GW. An allelic polymorphism within the human tumor necrosis factor alpha promoter region is strongly associated with HLA A1, B8, and DR3 alleles. $J$ Exp Med 1993; 177: 557-560.

31. Nadel S, Newport MJ, Booy R, Levin M. Variation in the tumor necrosis factor-alpha gene promoter region may be associated with death from meningococcal disease. $J$ Infect Dis 1996; 174: 878-880.

32. Westendorp RG, Langermans JAM, Huizinga TW et al. Genetic influence on cytokine production and fatal meningococcal disease. Lancet 1997; 349: 170-173.

33. Tubbs HR. Endotoxin in meningococcal infections. Arch Dis Child 1980; 55: 808-810.

34. Alexander HR, Wong GG, Doherty GM, Venzon DJ, Fraker DL, Norton JA. Differentiation factor/leukemia inhibitory factor protection against lethal endotoxemia in mice: synergistic effect with interleukin 1 and tumor necrosis factor. J Exp Med 1992; 175: 1139-1142.

35. Waring PM, Waring LJ, Billington T, Metcalf D. Leukemia inhibitory factor protects against experimental lethal Escherichia coli septic shock in mice. Proc Natl Acad Sci USA 1995; 92: 1337-1341.

36. Westendorp RGJ, Langermans JAM, Huizinga TWJ, Verweij CL, Sturk A. Genetic influence on cytokine production in meningococcal disease. Lancet 1997; 349: 1912-1913.

37. Read RC, Camp NJ, di Giovine FS et al. An interleukin-1 genotype is associated with fatal outcome of meningococcal disease. J Infect Dis 2000; 182: 1557-1560.

38. Brinkman BM, Zuijdeest D, Kaijzel EL, Breedveld FC, Verweij CL. Relevance of the tumor necrosis factor alpha (TNF alpha)-308 promoter polymorphism in TNF alpha gene regulation. J Inflamm 1995; 46: 32-41.

39. Fong Y, Tracey KJ, Moldawer LL et al. Antibodies to cachectin/tumor necrosis factor reduce interleukin lbeta and interleukin 6 appearance during lethal bacteremia. J Exp Med 1989; 170: $1627-1633$

40. Waage A, Espevik T. Interleukin 1 potentiates the lethal effect of tumor necrosis factor alpha/cachectin in mice. $J$ Exp Med 1988; 167: 1987-1992.

41. van Deuren $\mathrm{M}$, van der Ven-Jongekrijg J, Vannier E et al. The pattern of interleukin-1beta (IL-1beta) and its modulating agents IL-1 receptor antagonist and IL-1 soluble receptor type II in acute meningococcal infections. Blood 1997; 90 1101-1108.

42. Waage A, Halstensen A, Shalaby R, Brandtzaeg P, Kierulf P,
Espevik T. Local production of tumor necrosis factor alpha, interleukin 1, and interleukin 6 in meningococcal meningitis Relation to the inflammatory response. $J$ Exp Med 1989; 170: 1859-1867.

43. Shalaby MR, Halgunset J, Haugen OA et al. Cytokineassociated tissue injury and lethality in mice: a comparative study. Clin Immunol Immunopathol 1991; 61: 69-82.

44. Hazelzet JA, de Groot R, van Mierlo G et al. Complement activation in relation to capillary leakage in children with septic shock and purpura. Infect Immun 1998; 66: 5350-5356.

45. Frieling JT, van Deuren M, Wijdenes $\mathrm{J}$ et al. Interleukin-6 and its soluble receptor during acute meningococcal infections: effect of plasma or whole blood exchange. Crit Care Med 1996; 24: 1801-1805.

46. Arranz E, Blanco-Quiros A, Solis P, Garrote JA. Lack of correlation between soluble CD14 and IL-6 in meningococcal septic shock. Pediatr Allergy Immunol 1997; 8: 194-199.

47. Hack CE, De Groot ER, Felt-Bersma RJF et al. Increased plasma levels of interleukin-6 in sepsis. Blood 1989; 74: $1704-1710$

48. Ma X, Riemann H, Gri G, Trinchieri G. Positive and negative regulation of interleukin-12 gene expression. Eur Cytokine Netw 1998; 9 (3 Suppl): 54-64.

49. Trinchieri G. Interleukin-12: a cytokine at the interface of inflammation and immunity. Adv Immunol 1998; 70: 83-243.

50. Hazelzet JA, Kornelisse RF, van der Pouw Kraan TC et al. Interleukin 12 levels during the initial phase of septic shock with purpura in children: relation to severity of disease. Cytokine 1997; 9: 711-716.

51. Heinzel FP, Rerko RM, Ahmed F, Hujer AM. IFN-gammaindependent production of IL-12 during murine endotoxemia. J Immunol 1996; 157: 4521-4528.

52. Metcalf D. The leukemia inhibitory factor (LIF). Int J Cell Cloning 1991; 9: 95-108.

53. Guillet C, Fourcin M, Chevalier S, Pouplard A, Gascan H. ELISA detection of circulating levels of LIF, OSM, and CNTF in septic shock. Ann NY Acad Sci 1995; 762: 407-409.

54. Waring $P$, Wycherley K, Cary D, Nicola N, Metcalf D. Leukemia inhibitory factor levels are elevated in septic shock and various inflammatory body fluids. J Clin Invest 1992; 90: 2031-2037.

55. Villers D, Dao T, Nguyen J-M et al. Increased plasma levels of human interleukin for DA1.a cells/leukemia inhibitory factor in sepsis correlate with shock and poor prognosis. $J$ Infect Dis 1995; 171: 232-236.

56. Bogdan C, Nathan C. Modulation of macrophage function by transforming growth factor beta, interleukin-4, and interleukin-10. Ann NY Acad Sci 1993; 685: 713-739.

57. Brandtzaeg P, Osnes L, Øvstebø R, Joø GB, Westvik ̊-B, Kierulf P. Net inflammatory capacity of human septic shock plasma evaluated by a monocyte-based target cell assay: identification of interleukin-10 as a major functional deactivator of human monocytes. J Exp Med 1996; 184: 51-60.

58. de Waal Malefyt R, Abrams J, Bennett B, Figdor CG, de Vries JE. Interleukin 10 (IL-10) inhibits cytokine synthesis by human monocytes: an autoregulatory role of IL-10 produced by monocytes. J Exp Med 1991; 174: 1209-1220.

59. Howard M, Muchamuel T, Andrade S, Menon S. Interleukin 10 protects mice from lethal endotoxemia. J Exp Med 1993; 177: $1205-1208$.

60. Derkx B, Marchant A, Goldman M, Bijlmer R, van Deventer S. High levels of interleukin-10 during the initial phase of fulminant meningococcal septic shock. J Infect Dis 1995; 171: $229-232$.

61. Lehmann AK, Halstensen A, Sørnes S, Røkke O, Waage A. High levels of interleukin 10 in serum are associated with fatality in meningococcal disease. Infect Immun 1995; 63: 2109-2112.

62. Riordan FAI, Marzouk O, Thomson APJ, Sills JA, Hart CA. Proinflammatory and anti-inflammatory cytokines in meningococcal disease. Arch Dis Child 1996; 75: 453-454.

63. van Furth AM, Seijmonsbergen EM, Langermans JAM, Groeneveld PHP, de Bel CE, van Furth R. High levels of interleukin 10 and tumor necrosis factor alpha in cerebrospinal fluid during the onset of bacterial meningitis. Clin Infect Dis 1995; 21: 220-222.

64. Pradier O, Gerard C, Delvaux A et al. Interleukin-10 inhibits 
the induction of monocyte pro-coagulant activity by bacterial lipopolysaccharide. Eur J Immunol 1993; 23: 2700-2703.

65. Brown MA, Hural J. Functions of IL-4 and control of its expression. Crit Rev Immunol 1997; 17: 1-32.

66. Choi P, Reiser H. IL-4: role in disease and regulation of production. Clin Exp Immunol 1998; 113: 317-319.

67. Collins H, Flesch IE, Emoto M, Kaufmann SHE. Interleukin4 production in response to infection with intracellular bacteria. Adv Exp Med Biol 1998; 452: 75-83.

68. Mackiewicz A, Schooltink H, Heinrich PC, Rose-John S. Complex of soluble human IL-6-receptor/IL-6 up-regulates expression of acute-phase proteins. J Immunol 1992; 149: 2021-2027.

69. Frieling JTM, van Deuren M, Wijdenes J et al. Circulating interleukin-6 receptor in patients with sepsis syndrome. J Infect Dis 1995; 171: 469-472.

70. Zeni F, Tardy B, Vindimian M, Pain P, Gery P, Bertrand J-C. Soluble interleukin-6 receptor in patients with severe sepsis. J Infect Dis 1995; 172: 607-608.

71. Lien E, Liabakk N-B, Johnsen A-C, Nonstad U, Sundan A, Espevik T. Polymorphonuclear granulocytes enhance lipopolysaccharide-induced soluble p75 tumor necrosis factor receptor release from mononuclear cells. Eur J Immunol 1995; 25: 2714-2717.

72. Gårdlund B, Sjölin J, Nilsson A, Roll M, Wickerts C-J, Wretlind B. Plasma levels of cytokines in primary septic shock in humans: correlation with disease severity. $J$ Infect Dis 1995; 172: 296-301.

73. Nathan CF, Murray HW, Wiebe ME, Rubin BY. Identification of interferon-gamma as the lymphokine that activates human macrophage oxidative metabolism and antimicrobial activity. $J$ Exp Med 1983; 158: 670-689.

74. Kohler J, Heumann D, Garotta G et al. IFN-gamma involvement in the severity of gram-negative infections in mice. J Immunol 1993; 151: 916-921.

75. Bucklin SE, Russell SW, Morrison DC. Participation of IFNgamma in the pathogenesis of LPS lethality. Prog Clin Biol Res 1994; 388: 399-406.

76. Halstensen A, Ceska M, Brandtzaeg P, Redl H, Naess A, Waage A. Interleukin- 8 in serum and cerebrospinal fluid from patients with meningococcal disease. J Infect Dis 1993; 167: 471-475.

77. Carrol ED, Thomson APJ, Mobbs KJ, Hart CA. The role of RANTES in meningococcal disease. J Infect Dis 2000; 182: 363-366.

78. Waring PM, Presneill J, Maher DW et al. Differential alterations in plasma colony-stimulating factor concentrations in meningococcaemia. Clin Exp Immunol 1995; 102: 501-506.

79. Barthlen W, Stadler J, Lehn NL, Miethke T, Bartels H, Siewert JR. Serum levels of end products of nitric oxide synthesis correlate positively with tumor necrosis factor alpha and negatively with body temperature in patients with postoperative abdominal sepsis. Shock 1994; 2: 398-401.

80. Gagnon C, Leblond FA, Filep JG. Peroxynitrite production by human neutrophils, monocytes and lymphocytes challenged with lipopolysaccharide. FEBS Lett 1998; 431: 107-110.

81. Tsuneyoshi I, Kanmura Y, Yoshimura N. Nitric oxide as a mediator of reduced arterial responsiveness in septic patients. Crit Care Med 1996; 24: 1083-1086.

82. Grover R, Zaccardelli D, Colice G, Guntupalli K, Watson D, Vincent JL. An open-label dose escalation study of the nitric oxide synthase inhibitor, N(G)-methyl-L-arginine hydrochloride (546C88), in patients with septic shock. Glaxo Wellcome International Septic Shock Study Group. Crit Care Med 1999; 27: $913-922$

83. Avontuur JAM, Boomsma F, van den Meiracker AH, de Jong FH, Bruining HA. Endothelin-1 and blood pressure after inhibition of nitric oxide synthesis in human septic shock. Circulation 1999; 99: 271-275.

84. Petros A, Lamb G, Leone A, Moncada S, Bennett D, Vallance P. Effects of a nitric oxide synthase inhibitor in humans with septic shock. Cardiovasc Res 1994; 28: 34-39.

85. Baines PB, Stanford S, Bishop-Bailey D et al. Nitric oxide production in meningococcal disease is directly related to disease severity. Crit Care Med 1999; 27: 1187-1190.

86. Wong HR, Carcillo JA, Burckart G, Kaplan SS. Nitric oxide production in critically ill patients. Arch Dis Child 1996; 74: $482-489$.

87. Østerud B, Flaegstad T. Increased tissue thromboplastin activity in monocytes of patients with meningococcal infection: related to an unfavourable prognosis. Thromb Haemost 1983; 49: 5-7.

88. Domula M, Bykowska K, Wegrzynowicz Z, Lopaciuk S, Weissbach G, Kopec M. Plasma fibronectin concentrations in healthy and septic infants. Eur $J$ Pediatr 1985; 144: 49-52.

89. Hortells JL, Ibanez Estella JA, Perez de Vinaspre S, Sanchez Ibanez A, Gonzalez Barrio I. [Prognostic value of plasma levels of fibronectin in septic shock.] Enferm Infecc Microbiol Clin 1992; 10: 531-535.

90. Leclerc F, Martinot A, Beuscart R, Chenaud M, Diependaele JF, Mazurier C. Plasma fibronectin in severe infectious purpura of children. Crit Care Med 1986; 14: 1053-1054.

91. Blanco A, Guisasola JA, Solis P, Bachiller R, Gonzalez H. Fibronectin in meningococcal sepsis. Correlation with antithrombin III and protein C. Acta Paediatr Scand 1990; 79: $73-76$.

92. Riordan FA, Bestwick K, Thomson AP, Sills JA, Hart CA. Plasma fibronectin levels in meningococcal disease. Eur $J$ Pediatr 1997; 156: 451-453.

93. Hermans PWM, Hibberd ML, Booy R et al. 4G/5G promoter polymorphism in the plasminogen-activator-inhibitor-1 gene and outcome of meningococcal disease. Meningococcal Research Group. Lancet 1999; 354: 556-560.

94. Westendorp RGJ, Hottenga J-J, Slagboom PE. Variation in plasminogen-activator-inhibitor-1 gene and risk of meningococcal septic shock. Lancet 1999; 354: 561-563.

95. Peltola H. Meningococcal disease: still with us. Rev Infect Dis 1983; 5: 71-91

96. Ossege LM, Voss B, Wiethege T, Sindern E, Malin J-P. Detection of transforming growth factor beta 1 mRNA in cerebrospinal fluid cells of patients with meningitis by non-radioactive in situ hybridization. J Neurol 1994; 242: 14-19.

97. Mastroianni CM, Lancella L, Mengoni F et al. Chemokine profiles in the cerebrospinal fluid (CSF) during the course of pyogenic and tuberculous meningitis. Clin Exp Immunol 1998; 114: 210-214

98. Spanaus K-S, Nadal D, Pfister H-W et al. C-X-C and C-C chemokines are expressed in the cerebrospinal fluid in bacterial meningitis and mediate chemotactic activity on peripheral blood-derived polymorphonuclear and mononuclear cells in vitro. J Immunol 1997; 158: 1956-1964.

99. Sprenger H, Rösler A, Tonn P, Braune HJ, Huffmann G, Gemsa D. Chemokines in the cerebrospinal fluid of patients with meningitis. Clin Immunol Immunopathol 1996; 80: $155-161$.

100. Visser JJ, Scholten RJ, Hoekman K. Nitric oxide synthesis in meningococcal meningitis. Ann Intern Med 1994; 120 $345-346$

101. Dawson TM, Dawson VL, Snyder SH. A novel neuronal messenger molecule in brain: the free radical, nitric oxide. Ann Neurol 1992; 32: 297-311.

102. Wang $\mathrm{H}$, Bloom $\mathrm{O}$, Zhang $\mathrm{M}$ et al. HMG-1 as a late mediator of endotoxin lethality in mice. Science 1999; 285 : $248-251$
Footnote added in proof:

Hackett SJ et al. Meningococcal bacterial DNA load at presentation correlates with disease severity. Arch Dis Child 2001: in press. 